\title{
MEASURING THE GLOBALIZATION: ESTIMATION OF PROBLEMS AND WAYS OF PROVIDING A STEADY DEVELOPMENT OF UKRAINE
}

\section{Iryna Tarasenko}

\begin{abstract}
In the paper the modern trends of quantitative evaluation of level of globalization are examined, degree of countries remoteness from the global threats and index of steady development with recognition of foreign and domestic experience. Achievements on a way to steady development are examined and problems, which on the modern stage appeared before postsocialistic countries, including Ukraine, are determined. It is determined that the problem of providing the steady development of Ukraine needs complex decision both on state and regional, industrial and micro levels. For providing steady development of national economy on the whole and of separate industries of national economy the necessity of development of complex of measures (special purpose programs), which must be inferior to the decision of three basic blocks of questions - economic, ecological and social is grounded.
\end{abstract}

Keywords: Globalization, global problems and threats, degree of remoteness from the global threats, steady development, index of steady development, measurings of steady development, government special purpose program, strategy of development. 